\title{
Industrial research in crisis in east Germany
}

Bonn. Despite substantial government support, industrial research in east Germany is on the verge of collapse. Figures published earlier this month reveal an 80 per cent drop in the number of research staff in industry over the past three years.

Germany's research minister, Paul Krüger, says the government will continue its high level of direct support for such research. But he is also planning a programme to help establish high-technology industries in the new Länder as a way of encouraging more industrially relevant research and development.

The new figures, published by the Public Society for Science Statistics, are a major disappointment for the government, which has spent DM1.62 billion (US\$950 million) over the past three years on supporting the industrial research base in east Germany.

When the Berlin Wall was pulled down

in 1989 , about 86,000 people were employed in research departments in east German industry. This was judged to be an overcapacity of around 16,000 by western

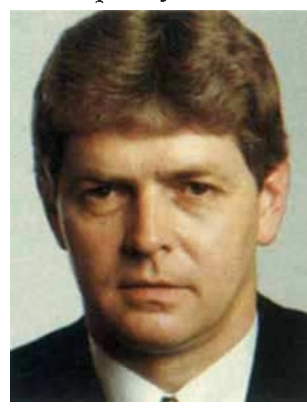

Krüger: admits errors.
German standards. Since then, the numbers have fallen rapidly. By 1991 , only 34,600 were employed in industrial research and development; the predicted figure for 1994 is 16,000 .

The fall partly reflects the declining fortunes of industry in the new Länder, following the collapse of its East European markets and the recession in the West. But this is not the whole story. The companies

\section{Differing views on technology transfer}

Bonn. A united Germany's first parliamentary debate on science and technology, which took place in Bonn earlier this month, underlined sharp differences between the political parties about how to improve the interaction between research and industry.

The debate was prompted by increasing political and economic pressure to improve efficiency of technology transfer. Germany has a strong economy and a well-financed and effective fundamental research base. But the two sectors do not work well together. The rate of increase in patent applications is falling, and Germany competes poorly with other countries in many hightechnology areas.

In October 1992, a report commissioned by the state of Baden-Württemberg recommended setting up a federal technology council. This five-member council, meeting under the aegis of the federal president, would make recommendations on the financing and organization of research judged necessary for long-term economic growth.

The report was put together by a committee dominated by a number of prominent German industrialists, but also including academics and politicians, and has stirred considerable controversy in political circles. The Christian Democrat party (CDU) has been divided in its response, while the Free Democrats, partners with the CDU in the ruling coalition government, oppose the recommendations, fearing they will encourage state interference in issues that should be left to industry.

In contrast, the opposition Social Democrats (SDP) support the creation of a technology council. But they want a much broader committee, with wider powers and members representing industry, politics and sci- ence. It would be responsible for developing a coordinated strategy for science, and for deciding on the financial and administrative changes required for its implementation.

Krüger believes that two committees he is setting up will achieve most, if not all, of the aims of the proposed technology council. One is a 14-strong 'strategy circle', set up last summer and made up of representatives from industry and science. This advises the minister on how conditions for research and technology transfer might be improved, and brings together scientists and industrialists with common interests.

In parallel, Krüger is setting up a group of more sharply focused 'dialogue circles' (Zieldialogkreis). These will look at individual scientific areas and identify precisely where industry could benefit from basic research, trying to predict the products that could be developed so that more goaldirected science policies can be defined.

The SDP does not think Krüger is going far enough, and dismisses the strategy circle as a debating society with no influence over government policy. It accuses the government of allowing research funding in Germany to fall at a time when greater investment is needed to ensure competitiveness.

The SDP says that if it wins next October's elections, it will make good the shortfall, calculated at about DM1 billion. All three major parties agree on one thing: much more deregulation is required to make life easier for academic and industrial scientists. The ministry of research and technology is already examining existing and proposed laws that impinge on research, and Krüger says he will shortly create a special section within the ministry to concentrate its efforts. Alison Abbott that have survived employ relatively few research staff; only 2 per cent of industrial employees work in research and development in the new Länder, compared to 4 per cent in the rest of Germany.

Krüger, who himself worked as a research group leader for a mechanical engineering firm in the former East Germany, is concerned at the extent of this decline.

"We give proportionately eight times more money to the new Länder for industrial research compared with the old Länder, and this is still not enough," he says. But he stresses that there is a limit to the amount of support the government is prepared to provide to an industry that is less successful than that in west Germany in delivering new products to the marketplace.

Krüger admits that different policies might have prevented the collapse of industrial research during the early days of reunification. During the restructuring period, for example, Treuhand - east Germany's privatization agency - encouraged the dismantling of the large conglomerates into smaller units, to prepare them for privatization.

At that time, most research departments were separated from their parent companies, and became independent contract research companies. But many now recognize this to have been a mistake. At least a third have not survived, and most of those that remain are heavily dependent on government subsidies. "At the time, researchers thought they would have a better future if they were independent," says Krüger. "They overestimated their potential."

Krüger says he regrets that Treuhand did nothing to discourage researchers from setting up independently, and that not enough money was made available during the transition period. He argues that Western standards were imposed too rapidly onto the east, and that too many research groups were left to sink or swim. "I would have tried to keep the research resources that were available, using government funds, to make the transition [to a capitalist economy] easier."

Given that products made in east Germany are generally uncompetitive on the world market, Krüger, while maintaining the many different programmes for support of industrial research, is also working with Treuhand and the Ministry of Industry on a new programme to encourage the development of more innovative, high-technology products in the east.

Details of the programme have not yet been finalized. But DM 150 million has been allocated to it by the government in 1994 . This money comes from funds belonging to the communist party of the former East German republic that are being used to rebuild the industrial base of the new Länder. 